\title{
Estimation of Age by Evaluating the Occlusal Tooth Wear in Molars: A Study on Dakshina Kannada Population
}

\author{
Amitha J Lewis $\mathbb{D}^{\prime}$ \\ Chandni Sreekumar ${ }^{2}$ \\ N Srikant' \\ Karen Boaz' \\ KP Nandita' \\ Nidhi Manaktala' \\ Shweta Yellapurkar' \\ 'Department of Oral Pathology and \\ Microbiology, Manipal College of Dental \\ Sciences, Mangalore, Manipal Academy of \\ Higher Education, Manipal, Karnataka, \\ 576104, India; ${ }^{2}$ Department of \\ Periodontics, Srinivas Institute of Dental \\ Sciences, Mangalore, Karnataka, 574 I46, \\ India
}

\begin{abstract}
Purpose: Assessment of teeth to estimate age in the living as well as the dead is well documented in the literature. Though applied in conjunction with other parameters in Gustafson's technique, attrition of teeth solely is an underexplored indicator for age estimation mainly in India. Most of the studies using attrition of teeth have been conducted in bioarchaeology, and in populations where studies are being conducted in forensic contexts, the results are debatable. Thus, the present study aimed to evaluate the accuracy of age estimation using the Average Stage of Attrition (ASA) method by Li and Ji in adults of the Dakshina Kannada region.
\end{abstract}

Materials and Methods: This cross-sectional study assessed the degree of attrition in both maxillary and mandibular first and second molars of 136 adults of Dakshina Kannada origin (age range: $20-70$ years) according to the 10 stages given by $\mathrm{Li}$ and $\mathrm{Ji}$ to derive populationspecific linear regression equations.

Results: Univariate analysis of prediction of age with attrition showed a significant association of attrition score with age, stratified by sex, arch as well as in total ( $p$-value $<0.001$ ) with a standard error of estimate of 9.231 years. The estimated age was within \pm 5 years of the actual age in $44.2 \%$ of the females and $50.0 \%$ of the males. A comparative review of 23 studies done to estimate age from attrition score clinically is documented in the manuscript. Conclusion: The findings of this study suggest that evaluation of tooth wear by the Average Stage of Attrition (ASA) method can be used as a non-invasive means to aid in the determination of age in adults of Dakshina Kannada origin. Although the error increases with age, this method provides a measurable means of seriation into older and younger categories.

Keywords: tooth attrition, age estimation, forensic odontology, occlusal wear, molars

\section{Introduction}

Age estimation is an important criterion that aids in establishing identity in anthropology as well as forensic odontology. Age estimation techniques are based on changes throughout lives that comprise growth and development and postformation changes. In accordance with this, age is estimated using different methods based on the fusion of sutures, development of teeth, regressive changes in teeth and skeletal development. ${ }^{1,2}$ Teeth being one of the strongest structures in the human body usually survive postmortem changes. ${ }^{3}$ Dental age estimation is more reliable as it is less variable and genetically controlled. ${ }^{4}$ Dental age assessment can be carried out in children and adolescents by the development and eruption pattern
Correspondence: N Srikant Department of Oral Pathology and Microbiology, Manipal College of Dental Sciences, Mangalore, Light House Hill Road, Mangalore, Manipal Academy of Higher Education, Manipal, Karnataka, 576104 , India

Tel +9196I I I44234

Email srikant.n@manipal.edu 
of the deciduous as well as permanent teeth for up to 14 years. ${ }^{2,5}$ After the age of 14, third molars are the only teeth still in development; hence, methods such as Demirjian's stages on the third molar can aid in determining whether an individual is above or below 18 years of age. ${ }^{6}$ For the estimation of age in adults older than 20 years, anthropologists and forensic experts may have to solely rely on ageassociated regressive changes. ${ }^{2,3,7}$

Teeth were first utilized for age estimation by Gustafson, ${ }^{8}$ who assessed six features that change with advancing age, with attrition being one of them. Enamel, covering the tooth, is the hardest structure of the human body. Yet, it is not free from age-associated changes. ${ }^{9}$ Enamel lacks regenerative potential after tooth eruption, unlike the other hard tissues (dentin, cementum, and bone) making enamel loss a permanent record of advancing age. This makes estimation of age from dental wear different from other methods. ${ }^{9}$ Tooth wear can occur by three main mechanisms, namely attrition, abrasion and erosion. Attrition is defined as the physiologic wearing away of the tooth surface due to tooth-to-tooth contact. Enamel attrition is a gradually advancing process. In newly erupted teeth the cusps are sharp with proper cuspal inclines and there is no sign of attrition. As age advances, attrition is visible and becomes more and more obvious with age. The cusps may exhibit wear facets, depressions or may completely wear away, exposing the underlying dentin or sometimes even the pulp cavity. ${ }^{1-3,5}$ Numerous studies have put forth age assessment by attrition, with Miles method being carried out and validated by a sizeable number of researchers along with modifications of his original method. Most of these methods were developed on prehistoric archaeological samples. A few other researchers have calibrated the amount of dental wear through correlation with pubic symphyseal age and determined that dental wear was as reliable as pubic symphyseal ageing. ${ }^{10} \mathrm{Li}$ and $\mathrm{Ji}$ reported a new method of estimation of age using the average of attrition levels of all cusps of maxillary and mandibular first and second molars. They established a new graduation standard and used it to determine age with a maximum error of 4.53 years. ${ }^{1}$ Kim et al utilized all the premolars and molars, a total of 16 permanent teeth to examine the degree of tooth wear. ${ }^{3}$ Except for third molars, molars are considered excellent sources of age at death by many scientists due to their relatively consistent enamel wear rates, distinct wear facets and eruption times. ${ }^{11}$ They have larger occlusal tables and are subjected to greater occlusal forces than the premolars. The first molar erupts at an early age of 6 years and exhibits more degree of wear than the second molars. Teeth that erupt early are exposed to more physiological wear with age and thus may be strong indicators for the determination of age. ${ }^{3}$

Tooth wear not only depends on age but also the sex of the individual, the composition of enamel, habits and cultural changes making attrition scores differ at varying levels in different populations. Thus, population-specific studies are essential to evaluate the accuracy of tooth wear as an estimator of chronological age. ${ }^{12,13}$ Hence, the present study was undertaken to evaluate the accuracy of the Average Stage of Attrition (ASA) method of recording tooth wear in determining age using permanent maxillary and mandibular molars in adults of Dakshina Kannada origin and derive population-specific equations to estimate the age.

\section{Materials and Methods}

The approval for the study was obtained from the Institutional Ethics Committee, Manipal College of Dental Sciences, Mangalore (Ref: No. 17077: dated 24 June 2017) prior to the commencement of the study. Based on the article "Age estimation from the permanent molar in Northeast China by the method of average stage of attrition" published inForensic Science International by authors $\mathrm{Li}$ and $\mathrm{Ji}^{1}{ }^{1}$ the correlation coefficient derived/reported is 0.529 . With an alpha error of $1 \%$ and a power of $99.999 \%$, the $Z$ values of the given alpha and beta values are 2.58 and 4.26. With this correlation coefficient and using the formula $N=$ $\frac{\left(Z_{1-\frac{\alpha}{2}}+Z_{1-\beta}\right)^{2}}{C^{2}}$ (where $\mathrm{c}$ is 0.589 calculated as $\mathrm{C}=0.5^{*} \ln [(1+\mid$ $r \mid) /(1-|r|)])$, the required sample size was estimated to be 135 . Thus, this cross-sectional study included 136 individuals (both maxillary and mandibular first and second molars) of the Dakshina Kannada region with an age range of 20 to 70 years. The patient's hospital number, place of residence and domicile (an indicator of proof representing Dakshina Kannada population), date of birth/age (verified during registration with Unique ID Number) and sex were recorded. Teeth with dental caries, restorations and those without antagonists were excluded from the study. The clinical examination was carried out at the dental chair using a mouth mirror with the oral cavity being well illuminated. All examinations were carried out by the same examiner under identical conditions. The degree of attrition based on the condition of enamel and the exposed condition of the dentin was considered in this study. Two researchers standardized their procedures and evaluation in 30 cases. During 
the training, a third independent examiner was referred to mitigate discrepancies. A magnifying lens was used and the degree of attrition was evaluated for every individual tooth based on the 10 stages of crown attrition criteria given by $\mathrm{Li}$ and Ji. ${ }^{1}$ The Average Stage of Attrition (ASA) was calculated taking into account each cusp of a tooth when evaluating the attrition degree from stages $0-7$ for each cusp (Figure 1). The eighth and ninth stages of attrition were estimated from the attrition condition of the entire occlusal surface.

\section{Statistical Analysis}

The statistical analysis was performed using SPSS 20.0 and the test of significance had an alpha error of 0.05 . The attrition scores were assessed for the median and interquartile range as the data was skewed. Kruskal-Wallis test was performed to compare the attrition scores with increasing class intervals of age. The association of the attrition score with sex was tested using the Mann-Whitney $U$-test. Association of age (continuous variable) and attrition scores (ordinal variable) were tested using simple linear regression analysis in total, stratified by sex and arch. In our study, age was the dependent variable and tooth wear scores were independent variables. The equations were based on the statistical regression formula $y=a+b x$. The equations were further evaluated with the inclusion of confounding agents of habit, the number of teeth attrited and sex. The equations reliability was confirmed using the standard error of estimates derived.

\section{Results}

The cohort of patients included 136 individuals with a mean age of $31.96 \pm 11.86$ years (median age of 28 years), with 66 males $(48.5 \%)$ and 70 females $(51.4 \%)$. On comparison of the attrition score between males and females, we found that the females (median 2.5, IQR 5.25) had marginally higher attrition score compared to males (Median 1.5, IQR 5.06) although not significant (p-value 0.359, Mann-Whitney $U$ value of 2100). Tests of association of age with attrition showed a significant association of attrition score with age, stratified by sex, arch as well as in total (p-value $<0.001$ ). The correlation of the age and the attrition score was done using Pearson's correlation represented as " $r$ " value, or Pearson's correlation coefficient. The correlation coefficient of $>0.8$ is considered excellent, $0.6-0.8$ is considered very good and 0.4-0.6 is considered good. Less than 0.6 is not a good clinically viable correlation. The correlation of age and attrition score among 136 teeth studied showed " $r$ " value of 0.631 with an error of 9.231 years. (Figure 2) The regression coefficients (" $r$ " value) ranged from 0.525 in females to 0.711 in males. The correlation was excellent for the maxillary arch $(r=0.814)$ and good for the mandibular $\operatorname{arch}(r=0.578)$. The standard error of estimation (SEE) of

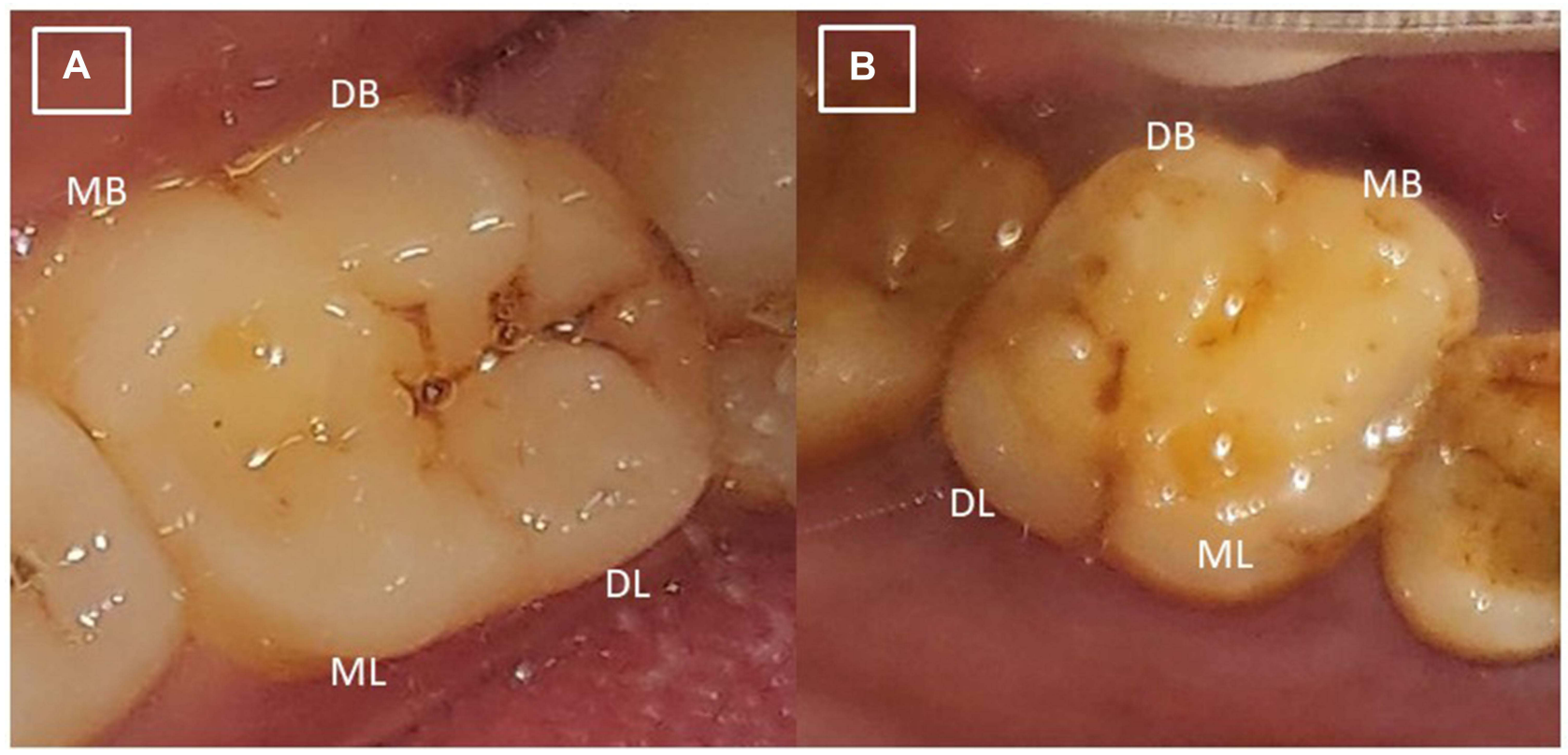

Figure I Average Stage of Attrition method on the molars. (A) Mesiobuccal cusp (Stage 4) + Distobuccal (Stage 0) + Distolingual (Stage 0) + Mesiolingual (Stage I) i.e, $\frac{4+0+0+1}{4}=1.25$ stage. (B) Mesiobuccal cusp (Stage 6) + Distobuccal (Stage 6) + Distolingual $\left(\right.$ Stage 5) + Mesiolingual $\left(\right.$ Stage 6). i.e, $\frac{6+6+5+6}{4}=5.75$ stage. 


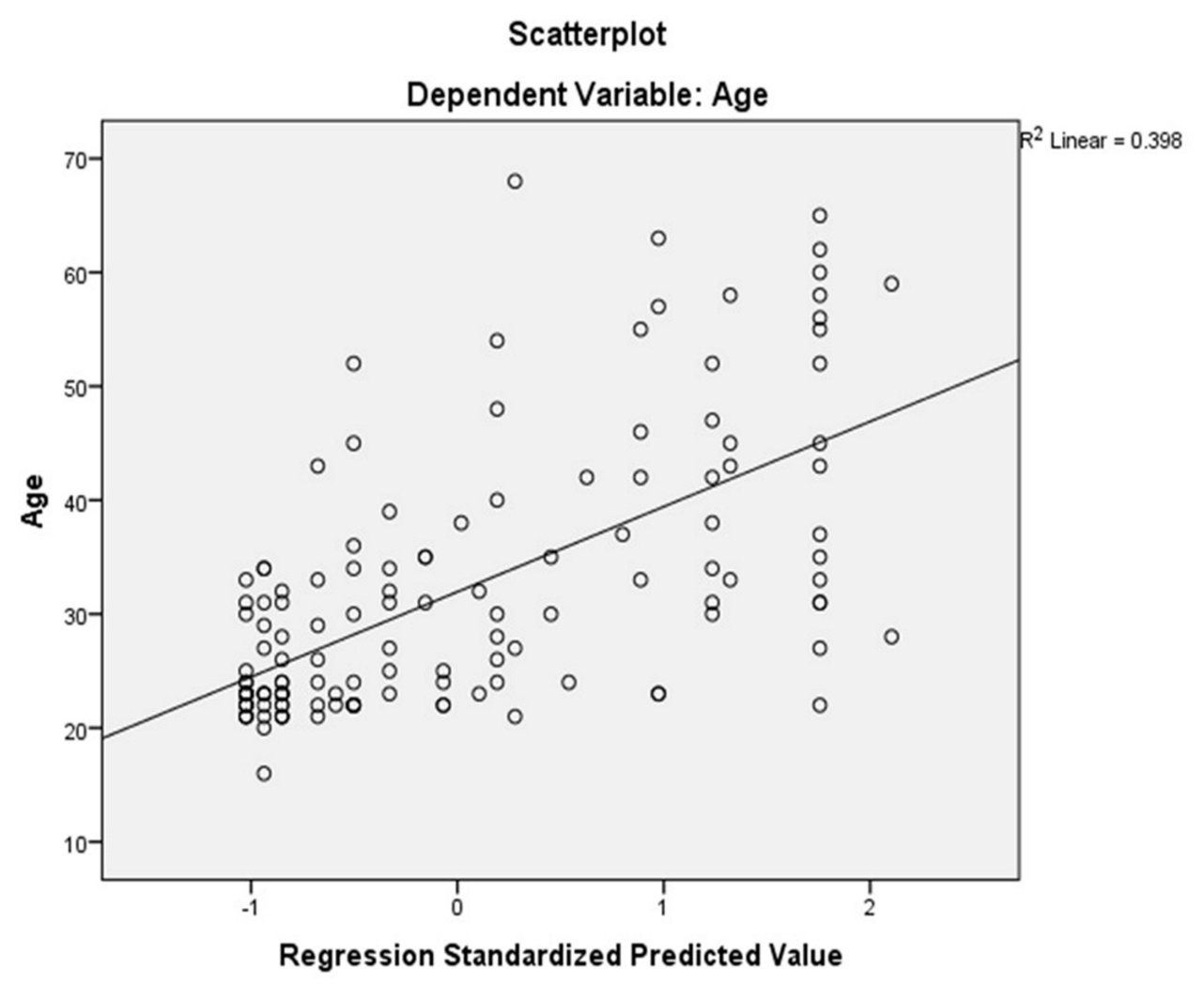

Figure 2 Scatter plot depicting the distribution of age, predicted by the equation derived by using the attrition score.

age was least in the maxillary arch (8.5 years) and highest in the male cohort (9.396 years) (Table 1).

To test if the habit, number of cusps involved play a role in the attrition, a multivariate linear regression analysis was performed including these parameters in the prediction equation. The female cohort showed a lack of significant association of attrition score after the inclusion of these variables; however, all the other stratifications and total cohort showed a significant association of the attrition score with the age of the individual. Overall cohort showed an " $r$ " value of 0.633 with an SEE of 9.071 years (Figures 2 and 3). The best predictor was that of the maxillary teeth attrition score with " $r$ " value of 0.819 with a SEE of 8.78 years (Table 1). Cubic and quadratic curve fitting were tried but it did not significantly improve the " $r$ " value. The " $r$ " values of both cubic and quadratic equations were 0.633 which was not substantially greater than the linear regression of 0.631 .

Comparison of the predicted and actual age showed a predominance of overestimation of age with an error of less than 5 years by attrition scores. There is no significant difference between sex and arches in the estimation of age. Males and maxillary arch had a higher proportion of underestimation of more than 10 years $(p>0.05)$. On comparison of the age categories, significantly higher underestimation of age was noted above 30 years of age $(\mathrm{p}<0.001)$ (Table 2).

The accuracy of estimation of age was evaluated in the present study by calculating the differences between estimated and actual ages. The results showed that the estimated age was within \pm 5 years of the actual age in $44.2 \%$ of the females and $50.0 \%$ of the males. On seriation into different age groups $<30,30-50$ and $>50$ years, the accuracy increased in the younger age group as demonstrated by the chi-square test of association. The percentage of individuals whose estimated age was within \pm 5 years of their actual age was $63.1 \%$ in individuals below the age of 30 . However, the accuracy decreased in the age range of 30-50, 36.3\% (Table 2). Kruskal-Wallis test shows an increasing trend of attrition score with increasing age (p-value $<0.001$ ). Table 3 shows a distribution of the mean, median and range of attrition scores with increasing age.

\section{Discussion}

In the field of forensic sciences, estimation of age at the time of the death of an individual due to mass disasters, natural calamities, following a crime, or in the case of 
Table I Univariate and Multivariate Linear Regression Analysis to Predict Age of an Individual Based on Attrition Score with/without Habit and Number of Cusps Involved Stratified by Sex and Arch Involved

\begin{tabular}{|c|c|c|c|c|c|}
\hline Group (N) & $\boldsymbol{R}$ & $\begin{array}{l}R^{2} \text { (Coefficient of } \\
\text { Determination) }\end{array}$ & $\begin{array}{l}\text { Std. Error of } \\
\text { the Estimate }\end{array}$ & Equation & $\begin{array}{l}\text { P-value (<0.05 is } \\
\text { Significant: Marked in } \\
\text { Red) }\end{array}$ \\
\hline \multicolumn{6}{|l|}{ Univariate analysis } \\
\hline Female (70) & 0.535 & 0.286 & 8.901 & Age $=25.71 \mathrm{I}+2.015$ (Attrition score) & $<0.001$ \\
\hline Male (66) & 0.711 & 0.505 & 9.396 & Age $=23.187+3.149$ (Attrition score) & $<0.001$ \\
\hline Maxillary (27) & 0.814 & 0.662 & 8.522 & Age $=24.564+3.724$ (Attrition score $)$ & $<0.001$ \\
\hline Mandibular (109) & 0.578 & 0.334 & 9.036 & Age $=24.4+2.259$ (Attrition score) & $<0.001$ \\
\hline Total (I36) & 0.631 & 0.398 & 9.231 & Age $=24.297+2.599($ Attrition score $)$ & $<0.001$ \\
\hline \multicolumn{6}{|c|}{ Multivariate analysis including the presence of chewing habit, number of cusps involved } \\
\hline Female (70) & 0.560 & 0.313 & 8.864 & $\begin{array}{l}\text { Age }=22.852+0.627 \text { (habit) }+2.603 \text { (Cusps } \\
\text { involved) }+0.884 \text { (Attrition score) }\end{array}$ & 0.279 \\
\hline Male (66) & 0.714 & 0.51 & 9.5 & $\begin{array}{l}\text { Age }=24.004-2.168 \text { (habit) }+-0.542 \text { (Cusps } \\
\text { involved) }+3.45 \text { I (Attrition score) }\end{array}$ & $<0.001$ \\
\hline Maxillary (27) & 0.819 & 0.67 & 8.776 & $\begin{array}{l}\text { Age }=24.755+3.253 \text { (habit) }+-0.55 \mathrm{I} \text { (Cusps } \\
\text { involved) }+3.875 \text { (Attrition score) }\end{array}$ & 0.002 \\
\hline Mandibular (109) & 0.585 & 0.342 & 9.071 & $\begin{array}{l}\text { Age }=23.519-1.482 \text { (habit) }+0.893 \text { (Cusps } \\
\text { involved) }+1.939 \text { (Attrition score) }\end{array}$ & 0.002 \\
\hline Total (I36) & 0.633 & 0.4 & 9.282 & $\begin{array}{l}\text { Age }=23.68 I-0.75 I \text { (habit) }+0.625 \text { (Cusps } \\
\text { involved) }+2.36 I \text { (Attrition score) }\end{array}$ & $<0.001$ \\
\hline
\end{tabular}

anthropology is of paramount importance. Due to the hardness and resistance of dental tissues to environmental factors, teeth can survive for several years or even decades and may sometimes be the only source available to estimate the age of an individual. An added advantage is that teeth can be directly examined in live individuals, thus providing valuable input regarding an individual's growth and development. ${ }^{14}$ At the same time, the development of teeth is less affected by malnutrition and other systemic factors than skeletal development making them reliable markers for age estimation. Estimation of age using teeth is possible as the teeth exhibit distinct age changes from the time of tooth development, mineralization and eruption to the attrition of crown, the formation of secondary dentin, translucency of the root and cementum formation. Thus, as with the whole body, teeth show changes with age. ${ }^{2,3,5}$

On review of English literature using the search terms "Attrition" "dental wear" for age estimation in Google Scholar, Scopus and PubMed, we found 23 studies from 1962 to 2020 . The studies mainly used the technique employed by Miles ( $\mathrm{n}=5)$, Brothwell $(\mathrm{n}=4)$, Murphy's $(n=2)$, Takei $(n=1)$, Dreier FG $(n=1), L i$ and Ji $(n=2)$, Kim ( $\mathrm{n}=2)$, Modified Kim's Method ( $\mathrm{n}=3)$, Smith $(\mathrm{n}=1)$, Mockers $(\mathrm{n}=1)$ and Pot $(\mathrm{n}=1){ }^{1-3,7,9,11-28}$ The range of SEE for each study was least to the maximum with " $r$ " values ranging from 0.3 to 0.97 . The " $r$ " value was highest in the Chinese population and the least in the urban Brazilian population $^{1,14}$ (Table 4).

The pattern of attrition depends not only on age but also to a lesser extent on food habits. Although equally distributed samples and appropriate regression models have yielded better " $r$ " values in different populations, we should be aware of various dietary preferences, which may influence tooth wear. Predominantly rice, vegetables and meat were prepared by steaming in the Chinese population as compared to softer commercially prepared packaged food in the urban Brazilian diet. The latter type induces less attrition. ${ }^{1,14}$

When Miles ${ }^{15}$ put forth a uniform method of evaluation of dental age using molars it was possible to estimate the individual's age in a given population with 


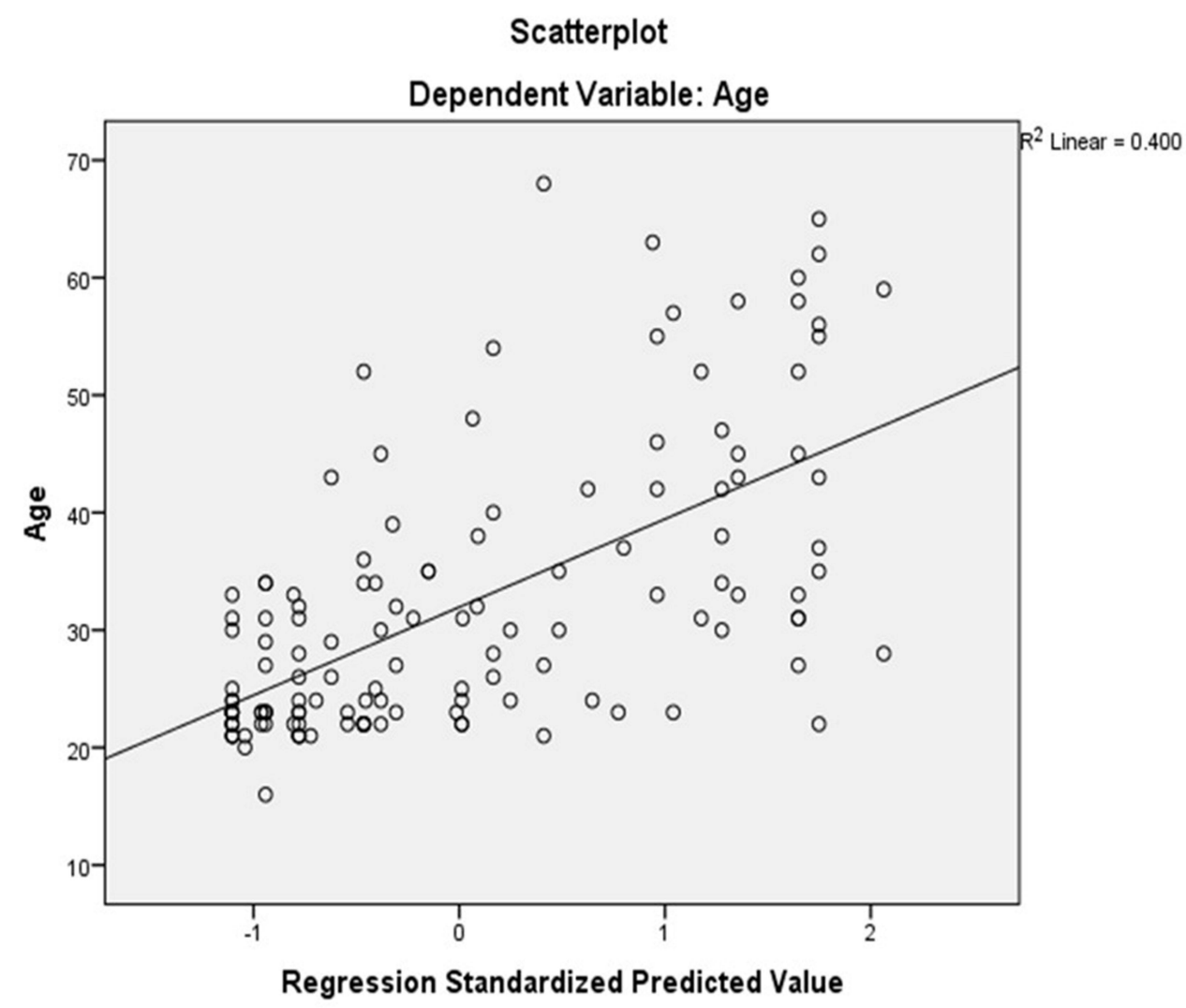

Figure 3 Scatter plot depicting the distribution of age, predicted by the equation derived by using the attrition score in the presence of confounding factors (habit and number of cusps involved).

a reasonable degree of accuracy. Brothwell ${ }^{17}$ derived a chart based on Miles' work $^{18}$ by using a simple ordinal scoring system to age British skeletal remains from Neolithic to Medieval times. Nowell et $\mathrm{al}^{12}$ and Kieser et $\mathrm{al}^{13}$ have provided the evidence for the reliability of the Miles method in ageing archaeological populations and have suggested that it performs as well or better than skeletal-based age estimation methods. However, a study by Solheim and Sundnes ${ }^{30}$ found the Miles method to be less reliable than those described by Bang and Ramn, Dalitz and Gustafson. They felt that the value for the Miles method was only since it is a non-destructive method. Following this Takei, ${ }^{20}$ Dreier, ${ }^{21} \mathrm{Li}$ and $\mathrm{Ji},{ }^{1} \mathrm{Kim}$ et $\mathrm{al}^{3}{ }^{3}$ have put forth new methods for age estimation using the attrition of teeth. Since the study conducted by Takei is in Japanese literature we have not included it in our review. However, Hongwei and Jingtao $^{20}$ have studied the method suggested by Takei in the Chinese population and found that it is reliable in younger age groups than older in the estimation of age. Yun et $\mathrm{al}^{24}$ and Gilmore et $\mathrm{al}^{9}$ have modified criteria put forth by $\mathrm{Kim}^{3}$ and Miles, ${ }^{13}$ respectively. The benefit of the ASA method by
$\mathrm{Li}$ and $\mathrm{Ji}^{1}$ is that it averages the attrition stages of all the cusps on a given molar overcoming the drawback of overestimation of age. They also concluded that the first molar is more reliable in the estimation of age and that one molar either maxillary or mandibular first or second molar is sufficient to estimate the age at death using the ASA method. ${ }^{1}$

In the present study, we used the criteria put forth by $\mathrm{Li}$ and $\mathrm{Ji}^{1}$ to derive population-specific regression equations to estimate the age. Our study showed a higher standard error of estimate ranging from 8.5 to 9.3 years in comparison to the original study by $\mathrm{Li}$ and $\mathrm{Ji}$, wherein among the six regression equations derived, the maximum error seen was 4.53 years. This is contrary to the studies done by Ajmal et $\mathrm{al}^{2}$ in the Indian population who studied three methods, namely Johanson method, Methods of Johanson and Kashyap and Average stage of Attrition, among which the attrition system was found to be the best to predict the age. They reported a standard deviation ranging from 2.7 to 3.9 years, which was an improvement to the original study conducted by Li and Ji. This could be because in the study conducted by Ajmal et al, ${ }^{2}$ they used extracted teeth 
Table 2 Accuracy of Age Estimation in Total, Stratified by Sex, Arch and Age

\begin{tabular}{|c|c|c|c|c|c|c|c|c|}
\hline & \multirow{2}{*}{$\begin{array}{l}\text { Total } \\
\text { n(\%) }\end{array}$} & \multicolumn{2}{|c|}{ Sex } & \multicolumn{2}{|c|}{ Arch } & \multicolumn{3}{|c|}{ Age } \\
\hline & & $\begin{array}{l}\text { Female } \\
\mathbf{n}(\%)\end{array}$ & $\begin{array}{l}\text { Male } \\
n(\%)\end{array}$ & $\begin{array}{l}\text { Maxillary } \\
n(\%)\end{array}$ & $\begin{array}{l}\text { Mandibular } \\
\mathrm{n}(\%)\end{array}$ & $\begin{array}{l}<30 \text { Years } \\
n(\%)\end{array}$ & $\begin{array}{l}\text { 30-50 Years } \\
n(\%)\end{array}$ & $\begin{array}{l}>50 \text { Years } \\
n(\%)\end{array}$ \\
\hline Overestimation $>10$ years & $13(9.6)$ & $8(11.4)$ & $5(7.6)$ & $\mathrm{I}(3.7)$ & $12(11)$ & $8(10.5)$ & $5(11.4)$ & $0(0)$ \\
\hline Overestimation $5-10$ years & $23(16.9)$ & $13(18.6)$ & $10(15.2)$ & $3(I I . I)$ & $20(18.3)$ & $19(25)$ & $4(9.1)$ & $0(0)$ \\
\hline Overestimation $<5$ years & $47(34.6)$ & $19(27.1)$ & $28(42.4)$ & $10(37)$ & $37(33.9)$ & $4 I(53.9)$ & $6(13.6)$ & $0(0)$ \\
\hline Underestimation $<5$ years & $17(12.5)$ & $12(17.1)$ & $5(7.6)$ & $\mathrm{I}(3.7)$ & $16(14.7)$ & $7(9.2)$ & $10(22.7)$ & $0(0)$ \\
\hline Underestimation $5-10$ years & $19(14)$ & $\mathrm{II}(15.7)$ & $8(12.1)$ & $5(\mid 8.5)$ & $14(12.8)$ & $\mathrm{I}(\mathrm{I} .3)$ & $16(36.4)$ & $2(12.5)$ \\
\hline Underestimation $>10$ years & $17(12.5)$ & $7(10)$ & $10(15.2)$ & $7(25.9)$ & $10(9.2)$ & $0(0)$ & $3(6.8)$ & |4(87.5) \\
\hline Chi-square ( $p$-value) & & \multicolumn{2}{|c|}{$6.581(0.253)$} & \multicolumn{2}{|c|}{$9.38(0.095)$} & \multicolumn{3}{|c|}{$141.866(\leq 0.001)$} \\
\hline
\end{tabular}

Table 3 Kruskal-Wallis Test Showing the Association of Attrition Score with Age Categories

\begin{tabular}{|c|c|c|c|c|c|c|}
\hline & $\mathbf{N}$ & Male & Female & Mean Attrition Score \pm SD & Median (IQR) & Range \\
\hline$<20$ & 2 & I & 1 & $0.25 \pm 0$ & $0.25(0.25,0.25)$ & $0.25-0.25$ \\
\hline $21-30^{\mathrm{a}, \mathrm{b}, \mathrm{c}, \mathrm{d}}$ & 74 & 40 & 34 & $1.62 \pm 2.09$ & $0.5(0.25,2.75)$ & $0-9$ \\
\hline $31-40^{\mathrm{a}}$ & 32 & 11 & 21 & $3.51 \pm 2.82$ & $2.5(1.25,6.5)$ & $0-8$ \\
\hline $4 I-50^{b}$ & 12 & 3 & 9 & $5.35 \pm 2.3$ & $6(4.13,6.75)$ & $\mathrm{I}-8$ \\
\hline $5 I-60^{c}$ & 12 & 8 & 4 & $6.54 \pm 2.2$ & $7.38(5.63,8)$ & $1.5-9$ \\
\hline $6 I-70^{d}$ & 4 & 3 & 1 & $6.38 \pm 2.05$ & $6.88(4.75,8)$ & $3.75-8$ \\
\hline Kruskal-Wallis test & \multicolumn{6}{|c|}{ Test value of 47.952 and $p$-value of $\leq \mathbf{0 . 0 0}$ I } \\
\hline
\end{tabular}

Notes: ${ }^{\text {a,b,c,d }}$ Symbols represent pairwise comparison. Similar symbols represent significant difference with a $\mathrm{p}$-value of $<0.05$ (Bonferroni correction).

of patients who had no history of pan chewing. In a real clinical development requiring age estimation of skeletal remains, we cannot expect an ideal scenario of the deceased being without habits. The presence of habit may hasten the attrition rates thereby resulting in higher error rates reported by our study. However, an advantage of $\mathrm{Li}$ and Ji's method ${ }^{1}$ is that even if a single molar is available as evidence, the age of the deceased can be narrowed down.

On comparison of the attrition score between sexes, females (3.1 \pm 2.78$)$ had a marginally higher attrition score compared to males $(2.78 \pm 2.99)$ although not significant (p-value 0.524). This was as per the studies conducted by Heithersay, ${ }^{31}$ Lovejoy et al, ${ }^{19}$ Dreier $^{21}$ and Lu et al. ${ }^{26}$ This could be attributed to some kind of dietary habit, cultural activity (like betel or pan chewing), bruxism or due to the fact that females possibly chew food more thoroughly than their male counterparts.

The present finding contradicts those put forth by Faillace et $\mathrm{al}^{7} \mathrm{Kim}$ et $\mathrm{al}^{3}{ }^{3}$ and Telang et $\mathrm{al}^{25}$ who found greater wear in males than females. Faillace et al found that the attrition was greater in males than females in young and middle adulthood, but the differences were not distinguishable in old adulthood. They also suggested that though sex differences do exist, they are not great enough to separate the method by sex. ${ }^{7}$ Similarly, Telang et al inferred that as age advances the wear scores of males and females may parallel each other. ${ }^{25}$

Our study showed that the estimated age was within \pm 5 years of the actual age in $44.2 \%$ of the females and $50.0 \%$ of the males. In a study conducted by Yun et al, ${ }^{24}$ the estimated age was within \pm 5 years of the actual age in $63.5 \%$ of the male and $64.0 \%$ of the female subjects, which was better than the present study. However, they utilized the modified Kim's scoring for the estimation of age. ${ }^{24}$ Similarly, Kim et al $^{3}$ estimated age within \pm 5 years of the actual age in $61.8 \%$ of the male and $63.3 \%$ of the female subjects. Both Kim et $\mathrm{al}^{3}$ and Yun et $\mathrm{al}^{24}$ found increased accuracy in younger individuals $(<45$ and $<49$ years, respectively) and the accuracy decreased in the older age group and these findings were similar to the present study where the accuracy was better in subjects below 30 years.

Though the attrition of teeth is a gradually advancing process, the extent of tooth wear may be dependent on the type of food intake and the method of preparation of food 
Table 4 Studies Based on Attrition Reported in English Literature and Their Clinical Significance

\begin{tabular}{|c|c|c|c|c|c|c|}
\hline $\begin{array}{l}\text { SL } \\
\text { No }\end{array}$ & $\begin{array}{l}\text { Author } \\
\text { Details }\end{array}$ & $\mathbf{n}$ & Study Population & $\begin{array}{l}\text { The Method Used } \\
\text { to Measure Attrition }\end{array}$ & $r$ Value & Clinical Significance \\
\hline I & $\begin{array}{l}\text { Miles } \\
(1962)^{15}\end{array}$ & $n=190$ & $\begin{array}{l}\text { Anglo-saxon } \\
\text { settlement (skeletal } \\
\text { remains) }\end{array}$ & Miles Method & Not applicable & $\begin{array}{l}\text { The ratio between rates of wear of } \\
\text { Ist, } 2 \text { nd and } 3 r d \text { molars is more or } \\
\text { less constant despite the nature of } \\
\text { the diet in different populations. }\end{array}$ \\
\hline 2 & $\begin{array}{l}\text { Akpata ES } \\
(1975)^{16}\end{array}$ & $\mathrm{n}=352$ & Nigeria (Africa) & $\begin{array}{l}\text { Murphy's classification } \\
\text { of attrition }\end{array}$ & $\begin{array}{l}r=0.928-0.979 \\
\text { for } 2 n d \text { and Ist } \\
\text { molar }\end{array}$ & $\begin{array}{l}\text { Attrition is an index of wear and } \\
\text { masticatory activity. }\end{array}$ \\
\hline 3 & $\begin{array}{l}\text { Nowell } \\
(1979)^{12}\end{array}$ & $\mathrm{n}=268$ & Tepe Hissar, Iran & Miles method & $\begin{array}{l}r=0.87 \\
93 \% \text { estimated } \\
\text { within } 5 \text { years }\end{array}$ & $\begin{array}{l}\text { Provided evidence of reliability and } \\
\text { validity of Miles method. } \\
\text { Not possible to derive reliable } \\
\text { demographic details from this sample. }\end{array}$ \\
\hline 4 & $\begin{array}{l}\text { Brothwell } \\
(1981)^{17,18}\end{array}$ & $\begin{array}{l}\text { Not } \\
\text { applicable }\end{array}$ & $\begin{array}{l}\text { British Neolithic to } \\
\text { Mediaeval groups }\end{array}$ & Not applicable & Not applicable & $\begin{array}{l}\text { Distinguishes young skulls from } \\
\text { those over } 40 \text { years of age. } \\
\text { Not useful in identifying those with } \\
\text { advanced age. }\end{array}$ \\
\hline 5 & $\begin{array}{l}\text { Kieser et al } \\
(1983)^{13}\end{array}$ & $n=202$ & $\begin{array}{l}\text { Paraguay stone casts } \\
\text { of living individuals }\end{array}$ & Miles method & $r=0.95$ & Found Miles method to be reliable. \\
\hline 6 & $\begin{array}{l}\text { Lovejoy CO } \\
(1985)^{19}\end{array}$ & $\mathrm{n}=332$ & $\begin{array}{l}\text { Libben population } \\
\text { (USA) }\end{array}$ & Murphy's classification & $\begin{array}{l}r=0.93 \\
e=0.96\end{array}$ & $\begin{array}{l}\text { Even attrition rates. } \\
\text { Compared to skeletal indicators, } \\
\text { attrition is the single best method. } \\
\text { Higher wear rates in females. }\end{array}$ \\
\hline 7 & $\begin{array}{l}\text { Hongwei and } \\
\text { Jingtao } \\
(1989)^{20}\end{array}$ & $\begin{array}{l}\mathrm{n}=24,640 \\
\text { (Teeth) } 880 \\
\text {-individuals }\end{array}$ & $\begin{array}{l}\text { Chinese (urban and } \\
\text { rural areas) }\end{array}$ & Takei 1970 & $\begin{array}{l}r=0.61-0.83 \\
5 \text {-year accuracy } \\
\text { is } 93.1-99.7 \%\end{array}$ & $\begin{array}{l}\text { Accuracy of estimation of age better in } \\
\text { lower age groups than in higher groups. }\end{array}$ \\
\hline 8. & $\begin{array}{l}\text { Santini et al } \\
(1990)^{11}\end{array}$ & $\mathrm{n}=60$ & $\begin{array}{l}\text { Chinese (caries-free } \\
\text { skulls) }\end{array}$ & Miles and Brothwell & $\begin{array}{l}r=0.46 \\
\text { SEE } 9.2-9.7 \\
\text { years }\end{array}$ & $\begin{array}{l}\text { Dental wear does not proceed at the } \\
\text { same rate in all the three molars. } \\
\text { Does not give a precise estimate of } \\
\text { age at death. }\end{array}$ \\
\hline 9. & $\begin{array}{l}\text { Dreier FG } \\
(1994)^{21}\end{array}$ & $n=143$ & $\begin{array}{l}\text { Arikara remains } \\
\text { (USA) }\end{array}$ & $\begin{array}{l}\text { Dreier and Scott } \\
\text { (New method) }\end{array}$ & $r=0.945-0.946$ & $\begin{array}{l}\text { Suitable for age } 35-40 \text { years } \\
\text { Sex differences exist. } \\
\text { Females show more variability. }\end{array}$ \\
\hline 10 & $\begin{array}{l}\mathrm{Li} \text { and } \mathrm{Ji} \\
(1995)^{1}\end{array}$ & $\begin{array}{l}n=633 \\
\text { Age: }|5-7| \\
\text { years }\end{array}$ & Chinese (skulls) & ASA method & $r=0.94-0.97$ & $\begin{array}{l}\text { One molar is sufficient to estimate } \\
\text { age at death. }\end{array}$ \\
\hline II & $\begin{array}{l}\text { Constandse- } \\
\text { Westermann } \\
(1997)^{22}\end{array}$ & $n=109$ & Zwolle, Netherlands & Pot method & $\begin{array}{l}r \text { not applicable } \\
\text { SEE: } 3.8 \text { males } \\
\text { and } \\
6.3 \text { females }\end{array}$ & $\begin{array}{l}\text { Based on the average rate of } \\
\text { attrition of the total sample/ } \\
\text { population high percentage of } \\
\text { correct classification into four age } \\
\text { classes can be obtained. }\end{array}$ \\
\hline 12 & $\begin{array}{l}\text { Kim et al } \\
(2000)^{3}\end{array}$ & $\begin{array}{l}n=383 \\
\text { Age: } 13-79 \\
\text { years }\end{array}$ & $\begin{array}{l}\text { Korean population } \\
\text { (casts of living } \\
\text { individuals of known } \\
\text { age) }\end{array}$ & Kim's scoring criteria & $\begin{array}{l}r=0.6645 \\
-0.757 \text { in males } \\
0.639-0.8193 \\
\text { in females } \\
\text { SEE: } 1.52 \text { yrs }\end{array}$ & $\begin{array}{l}\text { Simple reliable method. } \\
\text { Accuracy of } \pm 2-3 \text { years in } \\
\text { individuals }<25 \text { years. }\end{array}$ \\
\hline
\end{tabular}

(Continued) 
Table 4 (Continued).

\begin{tabular}{|c|c|c|c|c|c|c|}
\hline $\begin{array}{l}\text { SL } \\
\text { No }\end{array}$ & $\begin{array}{l}\text { Author } \\
\text { Details }\end{array}$ & $\mathbf{n}$ & Study Population & $\begin{array}{l}\text { The Method Used } \\
\text { to Measure Attrition }\end{array}$ & $r$ Value & Clinical Significance \\
\hline 13 & $\begin{array}{l}\text { Ajmal et al } \\
(200 I)^{2}\end{array}$ & $\begin{array}{l}n=100 \\
\text { Age: } 21-60 \\
\text { years }\end{array}$ & Mangalore, India & $\mathrm{Li}$ and Ji method & $\begin{array}{l}r \text { not reported } \\
\text { SEE: } 2.76-3.94\end{array}$ & $\begin{array}{l}\text { Shown ASA method is suitable for } \\
\text { the Indian population. }\end{array}$ \\
\hline 14 & $\begin{array}{l}\text { Oliveira et al } \\
(2006)^{23}\end{array}$ & $\mathrm{n}=298$ & $\begin{array}{l}\text { Prehistoric Brazilian } \\
\text { population }\end{array}$ & Brothwell chart & $\begin{array}{l}r \text { not applicable } \\
\text { SEE: } 8.22\end{array}$ & Satisfactory results. \\
\hline 15 & $\begin{array}{l}\text { Yun et al } \\
(2007)^{24} \\
\text { (Modified } \\
\text { Kim's scoring } \\
\text { system) }\end{array}$ & $\begin{array}{l}\mathrm{n}=1092 \\
\text { (pairs of } \\
\text { maxillary } \\
\text { and } \\
\text { mandibular } \\
\text { casts) }\end{array}$ & $\begin{array}{l}\text { Korean population } \\
\text { (casts) }\end{array}$ & $\begin{array}{l}\text { Modified Kim's scoring } \\
\text { system (changed the } \\
\text { selection of teeth and } \\
\text { degree of } \\
\text { classification) }\end{array}$ & $\begin{array}{l}r=0.903 \text { in } \\
\text { males } 0.917 \text { in } \\
\text { females } \\
\text { SEE: } 7.28 \text { and } \\
7.16 \text {, } \\
\text { respectively }\end{array}$ & $\begin{array}{l}\text { Reliable and accurate method. } \\
\text { Estimation of any age above } 20 \text { years. }\end{array}$ \\
\hline 16 & $\begin{array}{l}\text { Gilmore et al } \\
(20 \mid 2)^{9} \\
\text { (Modification } \\
\text { of Miles } \\
\text { method) }\end{array}$ & $n=311$ & $\begin{array}{l}\text { Hunter-gatherers } \\
\text { and pastoralist } \\
\text { populations with } \\
\text { diverse population } \\
\text { histories and diets }\end{array}$ & Modified Miles method & SEE: 5.4 years & $\begin{array}{l}\text { A viable option for age estimation in } \\
\text { skeletal samples. } \\
\text { Better than cranial suture closure } \\
\text { method. }\end{array}$ \\
\hline 17 & $\begin{array}{l}\text { Telang et al } \\
(20 \mid 4)^{25}\end{array}$ & $\begin{array}{l}\mathrm{n}=120 \\
\text { Casts } \\
\text { Age: } 13-70 \\
\text { years }\end{array}$ & Mysore, India & Kim's scoring criteria & $\begin{array}{l}r=0.898-0.959 \\
\text { SEE: } 73.3 \%- \\
76.6 \% \text { estimated } \\
\text { with an error of } \\
\pm 5 \text { years }\end{array}$ & $\begin{array}{l}\text { Indian population high level of } \\
\text { accuracy. }\end{array}$ \\
\hline 18 & $\begin{array}{l}\text { Vieira et al } \\
(2015)^{14}\end{array}$ & $n=223$ & $\begin{array}{l}\text { Indigenous Amazon } \\
\text { population }\end{array}$ & $\begin{array}{l}\text { Modified tooth wear } \\
\text { index from Mockers O } \\
\text { et al } 2004\end{array}$ & $\begin{array}{l}r=0.316 \text { for } \\
\text { Urban } \\
\text { population } \\
\text { SEE: } 6.9 \text { years }\end{array}$ & $\begin{array}{l}\text { Poor correlation with age in urban } \\
\text { populations. } \\
\text { A strong relationship with age in } \\
\text { indigenous amazon populations. }\end{array}$ \\
\hline 19 & $\begin{array}{l}\text { Lu et al } \\
(2017)^{26}\end{array}$ & $\begin{array}{l}n=190 \\
\text { Age: } 16-62 \\
\text { years }\end{array}$ & $\begin{array}{l}\text { Chinese Malaysian } \\
\text { adults }\end{array}$ & Modified Kim's index & $\begin{array}{l}r=0.906 \text { and } \\
0.86 \text { for males } \\
\text { and females } \\
\text { SEE: } 7.37 \text { and } \\
7.26, \\
\text { respectively }\end{array}$ & $\begin{array}{l}\text { Fairly accurate in individuals }<40 \\
\text { years of age. } \\
\text { Accuracy decreases with age. }\end{array}$ \\
\hline 20 & $\begin{array}{l}\text { Faillace et al } \\
(2017)^{7}\end{array}$ & $\begin{array}{l}\mathrm{n}=620 \\
\text { Age: }>15 \\
\text { years }\end{array}$ & $\begin{array}{l}\text { New Mexico } \\
\text { (Individuals from } \\
\text { different } \\
\text { background) }\end{array}$ & $\begin{array}{l}\text { Yun et al (Modified } \\
\text { Kim's scoring) } \\
\text { Prince et al }\end{array}$ & $\begin{array}{l}r=0.512 \\
\text { SEE: } 7.5 \text { years }\end{array}$ & $\begin{array}{l}\text { Age estimation from dental wear } \\
\text { possible for modern industrialized } \\
\text { populations. } \\
\text { Better correlation in individuals }<45 \\
\text { years of age. } \\
\text { Increasingly unreliable in older } \\
\text { individuals. }\end{array}$ \\
\hline 21 & $\begin{array}{l}\text { Santini et al } \\
(2017)^{27}\end{array}$ & $\begin{array}{l}n=50 \\
\text { Age: } 16-62 \\
\text { years }\end{array}$ & Chinese & Miles method & $\begin{array}{l}86 \% \text { Estimated } \\
\text { within } 5 \text { years }\end{array}$ & $\begin{array}{l}\text { Fairly accurate in individuals less than } \\
40 \text { years but accuracy decreases with } \\
\text { increase in age. }\end{array}$ \\
\hline
\end{tabular}

(Continued) 
Table 4 (Continued).

\begin{tabular}{|l|l|l|l|l|l|l|}
\hline $\begin{array}{l}\text { SL } \\
\text { No }\end{array}$ & $\begin{array}{l}\text { Author } \\
\text { Details }\end{array}$ & $\mathbf{n}$ & Study Population & $\begin{array}{l}\text { The Method Used } \\
\text { to Measure Attrition }\end{array}$ & $\boldsymbol{r}$ Value & Clinical Significance \\
\hline 22 & $\begin{array}{l}\text { Alayan et al } \\
(2018)^{28}\end{array}$ & $\mathrm{n}=50$ & Chinese skulls & Brothwell chart & $\begin{array}{l}r \text { not applicable } \\
\text { Accuracy of } 88 \%\end{array}$ & $\begin{array}{l}\text { Can be used as a reasonable method } \\
\text { of age estimation. Tooth wear } \\
\text { assessment between various } \\
\text { assessors was precise. }\end{array}$ \\
\hline 23 & $\begin{array}{l}\text { Bartholdy } \\
\text { et al (2019) }\end{array}$ & $\begin{array}{l}\mathrm{n}=95 \mathrm{I} \\
\text { Age: I-19 } \\
\text { years }\end{array}$ & $\begin{array}{l}\text { The Netherlands } \\
\text { (post-medieval } \\
\text { cemetery) }\end{array}$ & Smith's scoring & $\begin{array}{l}\text { r=0.964 } \\
\text { SEE: I.4 years }\end{array}$ & Recording of non-adult dental wear. \\
\hline 24 & $\begin{array}{l}\text { The present } \\
\text { study (2020) }\end{array}$ & $\begin{array}{l}\mathrm{n}=136 \\
\text { Age: } 20-70 \\
\text { years }\end{array}$ & $\begin{array}{l}\text { Dakshina Kannada } \\
\text { population }\end{array}$ & Li and ji method & $\begin{array}{l}r=0.63 \text { I } \\
\text { SEE: } 9.23 \text { I years }\end{array}$ & $\begin{array}{l}\text { In younger age group }<30 \text { years } \\
\text { Can categorize fairly into age groups. }\end{array}$ \\
\hline
\end{tabular}

in a given population. Populations with a diet based on abrasive, unrefined food may show increased levels of attrition. $^{14}$ In a study conducted among indigenous Amazon populations, Vieira et $\mathrm{al}^{14}$ found tooth wear to correlate strongly with age. However, they suggested that it may be a poor indicator of age in the urban Brazilian population. In contrast to this, Faillace et $\mathrm{al}^{7}$ demonstrated that age estimation from dental wear is possible for modern populations with comparable age intervals to other established methods. They found a reasonable range of error for individuals under 45 years, but the reliability reduced in older individuals. Currently, the diet in the South Indian population consists mainly of rice, ricebased products and refined food substances. This may lead to a lesser occlusal tooth wear, which may be the reason for the higher underestimation of age in adults above 30 years of age as seen in our study. This is in accordance with the study by Vieira et al. ${ }^{14}$ Occlusal wear in these individuals may be altered due to parafunctional habits like bruxism and/or erosion, the relationship of the teeth within the jaw, environmental conditions, medication, etc. ${ }^{19}$ At the same time, bio-physiological differences between each individual in a given population may lead to asymmetries across the dental arch, which may affect the reliability of age estimation. ${ }^{29}$ The rate of dental wear can also vary culturally, which is evident based on the usage of areca nut and betel quid chewing in the Indian population. Although Ball ${ }^{32}$ criticized the use of tooth attrition as the sole indicator of age estimation, he admitted that this method could be easily performed without any complex equipment. In spite of the drawbacks associated with the use of toothwear to estimate age, the forensic odontologist in some rare scenarios where invasive procedures may not be permitted especially in resolving disputes regarding the chronological age of people who have inadequate documents/limited information, and migrants may require to use this technique as a useful adjunct to estimate the age. $^{26}$ This is of great significance as there is a global surge in illegal immigration. ${ }^{24}$ It could also help in criminal cases wherein fragmented remains/molar teeth are the only evidence. We need to remember that age estimation is an art and not a precise science. Hence, there may be an element of subjectivity in age determination due to the variation in the biological processes involved. ${ }^{18}$ Age estimation therefore is most effective when multiple methods are used in conjunction. Thus, whenever feasible it should be combined with skeletal and biochemical methods in order to achieve more accurate results. ${ }^{7}$ The limitation of this study is that our sample size was limited to 136 samples; a larger sample size may possibly help to derive better regression formulae with lower error rates.

\section{Conclusion}

Attrition of teeth being a morphological method of age estimation, though very convenient to use can provide conflicting results. In our study, attrition was found to correlate reasonably well with age with the estimated age being within \pm 5 years of the actual age in $44.2 \%$ of the females and $50.0 \%$ of the males. However, given the fact that age estimation in older adults is difficult, categorizing it into a broad age category can prove to be useful. It can be a valuable adjunct tool to estimate age when 
invasive procedures cannot be performed. Studies utilizing attrition as a sole indicator of age are sparse, especially in India. Dental attrition in modern-day populations needs to be researched to further understand the interaction between attrition and other variables like modern diet, habits, ancestry and stress. Further population-specific studies should be carried out on a large sample size to add extra insights into the findings of our study.

\section{Ethics Approval and Informed Consent}

The study protocol was approved by the Institutional Ethics Committee of Manipal College of Dental Sciences, Mangalore (Ref. No. 17077: dated 24 June 2017) and all participants signed an informed consent that their data will anonymously be used for research purposes. The present study complied with the principles of the Declaration of Helsinki.

\section{Disclosure}

The authors report no conflicts of interest in this work.

\section{References}

1. Li C, Ji G. Age estimation from the permanent molar in northeast China by the method of average stage of attrition. Forensic Sci Int. 1995;75:189-196. doi:10.1016/0379-0738(95)01791-7

2. Ajmal M, Mody B, Kumar G. Age estimation using three established methods. A study on Indian population. Forensic Sci Int. 2001;122 (2-3):150-154. doi:10.1016/S0379-0738(01)00501-1

3. Kim YK, Kho HS, Lee KH. Age estimation by occlusal tooth wear. J Forensic Sci. 2000;45(2):303-309. doi:10.1520/JFS14683J

4. Pelsmaekers B, Loos R, Carelsl C, Derom C, Vlietinck R. The genetic contribution to dental maturation. J Dent Res. 1997;76 (7):1337-1340. doi:10.1177/00220345970760070201

5. Verma M, Verma N, Sharma R, Sharma A. Dental age estimation methods in adult dentitions: an overview. $J$ Forensic Dent Sci. 2019;11(2):57-63. doi:10.4103/jfo.jfds_64_19

6. Lewis AJ, Boaz K, Nagesh KR, et al. Demirjian's method in the estimation of age: a study on human third molars. J Forensic Dent Sci. 2015;7(2):153-157. doi:10.4103/0975-1475.155081

7. Faillace KE, Bethard JD, Marks MK. The applicability of dental wear in age estimation for a modern American population. Am J Phys Anthropol. 2017;164(4):776-787. doi:10.1002/ajpa.23318

8. Gustafson G, Malmö DO. Age determination on teeth. J Am Dental Assoc. 1950;41:45-54. doi:10.14219/jada.archive.1950.0132

9. Gilmore CC, Grote MN. Estimating age from adult occlusal wear: a modification of the miles method. Am J Phys Anthropol. 2012;149 (2):181-192. doi:10.1002/ajpa.22106

10. Prince DA, Kimmerle EH, Konigsberg LW. A Bayesian approach to estimate skeletal age-at-death utilizing dental wear. J Forensic Sci. 2008;53(3):588-593. doi:10.1111/j.1556-4029.2008.00714.x

11. Santini A, Land M, Raab GM. The accuracy of simple ordinal scoring of tooth attrition in age assessment. Forensic Sci Int. 1990;48(2):175-184. doi:10.1016/0379-0738(90)90110-K
12. Nowell GW. An evaluation of the miles method of ageing using the Tepe Hissar dental sample. Am J Phys Anthropol. 1978;49 (2):271-276. doi:10.1002/ajpa.1330490216

13. Kieser JA, Prestona CB, Evansa WG. Skeletal age at death: an evaluation of the miles method of ageing. J Archaeol Sci. 1983;10 (1):9-12. doi:10.1016/0305-4403(83)90121-8

14. Vieira EP, Barbosa MS, Quintão CC, Normando D, GuatelliSteinberg D. Relationship of tooth wear to chronological age among indigenous Amazon populations. PLoS One. 2015;10(1): e0116138. doi:10.1371/journal.pone.0116138

15. Miles AE. Assessment of the ages of a population of anglo-saxons from their dentitions. Proc R Soc Med. 1962;55(10):881-886.

16. Akpata ES. Molar tooth attrition in a selected group of Nigerians. Community Dent Oral Epidemiol. 1975;3(3):132-135. doi:10.1111/ j.1600-0528.1975.tb00294.x

17. Brothwell DR. Digging Up Bones. 3rd ed. London: Natural History Museum Publications; 1981.

18. Miles AEW. The miles method of assessing age from tooth wear revisited. J Archaeol Sci. 2001;28:973-982. doi:10.1006/jasc.2000.0652

19. Lovejoy CO. Dental wear in the Libben population: its functional pattern and role in the determination of adult skeletal age at death. $\mathrm{Am}$ J Phys Anthropol. 1985;68(1):47-56. doi:10.1002/ajpa.1330680105

20. Hongwei S, Jingtao J. The estimation of tooth age from attrition of the occlusal surface. Med Sci Law. 1989;29(1):69-73.

21. Dreier FG. Age at death estimates for the protohistoric Arikara using molar attrition rates: a new quantification method. Int J Osteoarchaeol. 1992;4:137-147. doi:10.1002/oa.1390040206

22. Constandse-Westermann TS. Age estimation by dental attrition in an independently controlled early 19th century sample from Zwolle, The Netherlands. Hum Evol. 1997;12:269-285. doi:10. 1007/BF02438180

23. Oliveira RN, Silva SFSM, Kawanoa A, Antunes JLF. Estimating age by tooth wear of prehistoric human remains in Brazilian archaeological sites. Int J Osteoarchaeol. 2006;16:407-414. doi:10.1002/oa.840

24. Yun JI, Lee JY, Chung JW, Kho HS, Kim YK. Age estimation of Korean adults by occlusal tooth wear. J Forensic Sci. 2007;52 (3):678-683. doi:10.1111/j.1556-4029.2007.00414.x

25. Telang LA, Patil K, Mahima VG. Age estimation of an Indian population by using the Kim's scoring system of occlusal tooth wear. J Forensic Dent Sci. 2014;6(1):16-24. doi:10.4103/09751475.127765

26. Lu CK, Yee MCS, Ravi SB, Pandurangappa R. Forensic age estimation of Chinese Malaysian adults by evaluating occlusal tooth wear using modified Kim's index. Int J Dent. 2017;2017:4265753. doi: $10.1155 / 2017 / 4265753$

27. Santini A, Aldossary MS, Alayan I. Validation of the efficacy of age assessment by the Miles tooth wear chart, using skulls of known age at death. Int $J$ Forensic Odontol. 2017;2:55-61. doi:10.4103/ijfo. ijfo_11_17

28. Alayan I, Aldossary MS, Santini A. Validation of the efficacy of age assessment by the Brothwell tooth wear chart, using skulls of known age at death. J Forensic Dent Sci. 2018;10(1):18-21. doi:10.4103/jfo. jfds_15_17

29. Bartholdy BP, Hoogland MLP, Waters-Rist A. How old are you now? A new ageing method for nonadults based on dental wear. Int J Osteoarchaeol. 2019;29:622-633. doi:10.1002/oa.2758

30. Solheim T, Sundnes PK. Dental age estimation of Norwegian adultsa comparison of different methods. Forensic Sci Int. 1980;16 (1):7-17. doi:10.1016/0379-0738(80)90174-7

31. Heithersay GS. Further observations on the dentition of the Australian aborigine at Haast's Bluff. Aust Dent J. 1961;6:18-28. doi:10.1111/j.1834-7819.1961.tb03196.x

32. Ball J. A critique of age estimation using attrition as the sole indicator. J Forensic Odontostomatol. 2002;20(2):38-42. 


\section{Publish your work in this journal}

Clinical, Cosmetic and Investigational Dentistry is an international, peer-reviewed, open access, online journal focusing on the latest clinical and experimental research in dentistry with specific emphasis on cosmetic interventions. Innovative developments in dental materials, techniques and devices that improve outcomes and patient satisfaction and preference will be highlighted. The manuscript management system is completely online and includes a very quick and fair peer-review system, which is all easy to use. Visit http://www.dovepress.com/testimonials.php to read real quotes from published authors. 